\title{
APLIKASI KUESIONER PRA SKRINNING PERKEMBANGAN ANAK BERBASIS ANDROID DI HOMPIMPA CENTER BENGKALIS
}

\author{
Emilia Kartika Dewi ${ }^{1}$, Uci Rahmalisa ${ }^{2}$, Anita Febriani ${ }^{3}$ \\ ${ }^{1,2}$ Sistem Informasi, STMIK Hang Tuah Pekanbaru \\ ${ }^{3}$ Teknik Informatika, STMIK Hang Tuah Pekanbaru \\ 1emiliakartika28@gmail.com, ${ }^{2}$ ucirahmalisa89@gmail.com, ${ }^{3}$ nitasuheri@gmail.com
}

\begin{abstract}
Abstrak
Kuesioner Pra Skrining Perkembangan (KPSP) merupakan salah satu alat skrining/deteksi yang diwajibkan oleh Depkes untuk digunakan ditingkat pelayanan kesehatan primer. Psikolog memiliki peran yang signifikan sebagai tenaga ahli yang memiliki kewenangan dalam masalah perkembangan anak, termasuk kewenangan deteksi adanya penyimpangan perkembangan anak. Namun, psikolog dalam melayani skrining perkembangan dengan menggunakan KPSP masih bersifat manual yaitu masih menggunakan kertas kuesioner. Tujuan penelitian ini adalah membangun Aplikasi Kuesioner Pra Skrining Perkembangan Anak Berbasis Android yang dapat mempermudah psikolog dalam mengisi jawaban kuesioner dari orang tua secara efektif dan efisien, mempermudah psikolog dalam melakukan perhitungan kuesioner, serta mempercepat dalam pembuatan laporan hasil kuesioner. Metode penelitian ini menggunakan metode waterfall dan data dianalisa dengan menggunakan metode PIECES. Penelitian ini menghasilkan Aplikasi Kuesioner Pra Skrinning Perkembangan Anak Berbasis Android yang mana dapat membantu kinerja psikolog dalam melayani klien yang memiliki masalah dalam perkembangan anak. Aplikasi ini juga memberikan efisiensi waktu serta mempermudah dan mempercepat kinerja psikolog, serta dapat memberikan informasi tentang perkembangan anak dalam bentuk grafik, sehingga bisa mengetahui perkembangan anak secara periode.
\end{abstract}

Kata Kunci: Aplikasi, Kuesioner, Android.

\section{Pendahuluan}

Pembinaan tumbuh kembang anak secara komprehensif dan berkualitas diselenggarakan melalui kegiatan stimulasi, deteksi dan intervensi dini penyimpangan tumbuh kembang balita dilakukan pada "masa kritis". Melakukan stimulasi yang memadai artinya merangsang otak balita sehingga perkembangan kemampuan gerak, bicara dan bahasa, sosialisasi dan kemandirian pada balita berlangsung secara optimal sesuai dengan umur anak. Melakukan deteksi dini penyimpangan tumbuh kembang artinya melakukan skrining atau mendeteksi secara dini adanya upaya penyimpangan tumbuh kembang balita termasuk menindak lanjuti setiap keluhan orang tua terhadap masalah tumbuh kembang anaknya. Melakukan intervensi dini penyimpangan tumbuh kembang balita artinya melakukan tindakan koreksi dengan memanfaatkan plastisitas otak anak untuk memperbaiki penyimpangan tumbuh kembang pada seorang anak agar tumbuh kembangnya kembali normal atau penyimpangannya tidak semakin berat. Namun, apabila balita perlu dirujuk, maka rujukan juga harus dilakukan sedini mungkin sesuai dengan indikasi, dimana tindakan intervensi hanya dapat dilakukan oleh tenaga kesehatan terlatih baik ditingkat puskesmas maupun rumah sakit untuk mendapatkan pemerikasaan dan penanganan lebih lanjut.

Kuesioner Pra Skrining Perkembangan (KPSP) merupakan salah satu alat skrining/deteksi yang diwajibkan oleh Depkes untuk digunakan di tingkat pelayanan kesehatan primer. Kuesioner Pra skrinning Perkembangan atau disebut KPSP merupakan suatu daftar pelayanan singkat yang ditujukan kepada para orang tua dan digunakan sebagai alat untuk melakukan skrinning pendahuluan perkembangan anak usia 3 bulan sampai dengan 72 bulan (Dhamayanti, 2006).

Pendeteksian tumbuh kembang anak harus dilakukan sedini dan seakurat mungkin, sehingga apabila ada penyimpangan perkembangan anak dapat diketahui lebih dini dan dapat dicarikan solusi atas penyimpangan tersebut. Disamping tenaga medis, psikolog memiliki peran yang signifikan sebagai tenaga ahli yang memiliki kewenangan dalam masalah perkembangan anak, termasuk kewenangan deteksi adanya penyimpangan perkembangan anak. Adapun, kesadaran dan kebutuhan para orang tua akan perkembangan anak terus menunjukkan peningkatan. Dimana, salah satu tujuan konsultasi para orang tua adalah psikolog, baik untuk deteksi dini, diagnosa maupun intervensi (terapi) tumbuh kembang.

Sementara itu, di Hompimpa Center Bengkalis dalam melayani skrining tumbuh 
kembang dengan menggunakan salah satunya Kuesioner Pra Skrinning Perkembangan (KPSP) masih bersifat manual yaitu masih menggunakan kertas kuesioner. Hal ini berdampak pada penggunaan kertas yang terus menerus dan psikolog kesulitan dalam proses perhitungan hasil kuesioner tiap kertasnya, yang mana masingmasing pertanyaan memiliki indikator berbedabeda, serta membutuhkan waktu yang lama untuk mendapatkan laporan hasil skrining. Sehingga layanan masih bersifat individual, butuh waktu yang lama, dan belum mampu melayani klien skrinning tumbuh kembang secara kolektif/kelompok. Dimana hasil laporan ini nanti juga bisa dijadikan salah satu syarat untuk bisa masuk kesekolah dengan didampingi dengan surat pengantar. Seiring dengan perkembangan IPTEK, saat ini smartphone merupakan suatu kebutuhan bagi masyarakat, dengan cerdas dalam penggunakan android maka dapat mengatasi salah satu permasalahan yang dihadapi.

Berdasarkan permasalahan tersebut diperlukan suatu aplikasi kuesioner berbasis android guna meningkatkan layanan psikolog, serta memberikan informasi atau data mengenai tumbuh kembang anak. Sehingga dalam penelitian ini akan dijadikan bahan skripsi dengan judul "Aplikasi Kuesioner Pra Skrining Perkembangan Anak Berbasis Android di Hompimpa Center Bengkalis".

\section{Tinjauan Pustaka}

\subsection{Kajian terdahulu}

Beberapa penelitian yang telah membahas tentang aplikasi perkembangan anak, diantaranya Syafitry, dkk (2012) dalam penelitian yang berjudul Sistem Pakar Gangguan Perkembangan Pada Balita Berbasis Web dapat disimpulkan bahwa sistem yang telah dibangun dapat membantu orangtua dalam mengetahui gangguan perkembangan balita sesuai dengan analisa pakar perkembangan balita yaitu sebesar 83,33\%, memberikan informasi seputar tumbuh kembang balita, serta aplikasi ini juga menerapkan metode Dempster-Shafer, untuk membantu dalam proses perhitungan hasil akhir yang nilainya densitas (kepercayaan).

Selain menggunakan metode DempsterShafer sebagai penghitung nilai akhir, ada juga penelitian membahas tentang Penerapan Model Hybrid Mobile Development Pada Deteksi Dini Tumbuh Kembang Balita Berbasis Android untuk membantu para orangtua mengetahui status gizi balita menggunakan metode Z-Skor dan mendeteksi dini penyimpangan tumbuh kembang balita menggunakan metode Kuesioner Pra Skrining Perkembangan (KPSP) (Rizqy, dkk, 2015).

Penelitian lain yang berhubungan dengan tumbuh kembang anak telah dilakukan oleh Ariestyani, dkk (2016) dengan judul Klasifikasi Penyimpangan Tumbuh Kembang Anak
Menggunakan Metode Extreme Learning Machine (ELM) untuk melakukan klasifikasi penyimpangan tumbuh kembang anak dengan hasil akurasi terbaik dengan cara mengubah pilihan jawaban pada gejala yang dialami oleh anak dengan nilai 1 untuk pilihan ya dan nilai 0 untuk pilihan tidak. Kemudian nilai tersebut diolah dengan menggunakan algoritma ELM hingga didapatkan nilai keluaran output layer, nilai ini nanti digunakan untuk menentukan hasil klarifikasi dengan memilih nilai tertinggi.

Mulyani dan Restianie (2016) dengan judul Aplikasi Sistem Pakar untuk Mediagnosa Penyakit Anak (Balita) dengan Menggunakan Metode Forward Chaining. Dapat disimpulkan bahwa aplikasi sistem pakar ini dapat mendianogsa suatu penyakit anak (balita) yang sering diderita berdasarkan gejala yang dialami, kemudian dapat memberikan informasi penyakit tersebut beserta solusinya. Dengan diberikan interface yang user friendly maka aplikasi sistem pakar mudah dipelajari dan mudah digunakan untuk kalangan orang awam, sehingga dapat mempermudah dalam mendiagnosa penyakit.

Selanjutnya penelitian tentang perancangan yang dilakukan oleh Widodo, dkk (2014) yang berjudul Perancangan Sistem Pakar Deteksi Dini Tumbuh Kembangan Anak Berbasis Multimedia untuk membantu para tenaga kesehatan, kader dan terutama orang tua agar memiliki pemahaman yang benar dan cepat dalam mendiagnosa keterlambatan perkembangan balita. Hasil akhir dari penelitian ini berupa prototype sistem pakar dalam melakukan skrining tumbuh kembang balita dan anak prasekolah yang berbasis multimedia dengan acuan Kuesioner Pra Skrining Perkembangan (KPSP) beserta saran yang sesuai dengan hasil skrining. Dari hasil ini menunjukkan bahwa prototype sistem pakar mampu membantu orang tua untuk memahami isi kuesioner dengan lebih baik dan dapat melakukan skrining secara lebih akurat.

Sedangkan menurut Saurina (2016) dalam penelitian yang berjudul Aplikasi Deteksi Dini Tumbuh Kembang Anak Usia Nol Hingga Enam Tahun Berbasis Android untuk orang tua serta tim medis kesehatan yang bertugas di Puskesmas guna memberikan informasi mengenai tumbuh kembang anak, menemukenali penyimpangan pertumbuhan dan dapat memberikan saran stimulasi dini apa yang harus diberikan kepada anak.

\subsection{Landasan Teori}

\subsubsection{Konsep Tumbuh Kembang Anak}

Anak merupakan bagian yang sangat penting dalam kelangsungan kehidupan suatu bangsa. Anak merupakan sumber daya manusia bagi pembangunan suatu bangsa, penentu masa depan, dan penerus generasi keluarga sekaligus bangsa. Oleh karena itu, anak harus dalam kondisi yang sehat. Oleh karena itu, kesehatan anak baik dalam 
aspek pertumbuhan maupun perkembangan menjadi hal yang penting untuk dijaga sejak dini agar pertumbuhan dan perkembangan anak optimal. Untuk mendapatkan tumbuh kembang yang optimal perlu didukung oleh proses deteksi tumbuh kembang anak sejak dini agar para orang tua dapat memberikan stimulasi yang tepat untuk anak-anak mereka. Proses deteksi menjadi hal yang tidak boleh dianggap remeh demi terciptanya generasi penerus yang berkualitas yang mampu tumbuh dan berkembang baik secara fisik, emosional, maupun sosial (Wati, 2016).

\subsubsection{Kuesioner Pra Skrining Perkembangan (KPSP)}

Menurut Departemen Kesehatan (2006) Dinas kesehatan bekerjasama dengan Ikatan Dokter Anak Indonesia (IDAI) telah menyusun berbagai instrumen stimulasi, deteksi dan intervensi dini tumbuh kembang untuk anak umur 3 bulan sampai dengan 72 bulan yaitu dengan Kuesioner Pra Skrining Perkembangan (KPSP). Instrumen ini ditujukan bukan hanya untuk tenaga kesehatan di Puskesmas, dokter, bidan, perawat, ahli gizi, penyuluh kesehatan masyarakat, dan psikolog tetapi juga untuk petugas sektor lainnya dalam menjalankan tugas melakukan stimulasi dan deteksi dini penyimpangan tumbuh kembang anak.

Tujuan skrining/pemeriksaan perkembangan anak menggunakan KPSP adalah untuk mengetahui perkembangan anak normal atau ada penyimpangan. Alat/instrumen yang diguanakan diantaranya:

1) Formulir Kuesioner Pra Skrining Perkembangan (KPSP) menurut umur. Formulir ini berisi 9-10 pertanyaan tentang kemampuan perkembangan yang telah dicapai anak. Sasaran KPSP anak umur 0-72 bulan.

2) Alat bantu pemerikasaan berupa: pensil, kertas, bola sebesar bola tenis, kerincingan, kubus berukuran sisi 2,5 cm sebanyak 6 buah, kismis, kacang, kacang tanah, potongan biskuit kecil berukuran $0.5-1 \mathrm{~cm}$.

KPSP terdiri ada 2 macam pertanyaan yaitu pertanyaan yang dijawab oleh ibu/pengasuh anak dan perintah kepada ibu/pengasuh anak untuk melaksanakan tugas yang tertulis pada KPSP. Untuk mendapatkan hasil dari KPSP ini berikut proses perhitungnya:

1) Apabila jawaban ya 9-10 dianggap perkembangan anak sesuai dengan tahap perkembangannya (sesuai).

2) Apabila jumlah jawaban Ya 7 atau 8 perkembangan anak meragukan.

3) Apabila jumlah jawaban Ya 6 atau kurang, kemungkinan ada penyimpangan dalam perkembangan anak

\subsubsection{MySQL}

MySQL (My Structure Query Language) adalah salah satu Database Management System (DBMS) dari sekian banyak DBMS seperti Oracle, MS SQL, Postagre SQL, dan lainnya. MySQL berfungsi untuk mengolah database menggunakan bahasa SQL. MySQL bersifat open source sehingga bisa menggunakannya secara gratis (Anhar, 2010).

\subsubsection{Android Studio}

Android studio adalah IDE resmi untuk membangun aplikasi android berdasarkan Intellij IDEA. Intellij IDEA sendiri adalah Java Integrated Development Environment (IDE) yang dikembangkan oleh JetBrains, untuk mengembangkan perangkat lunak komputer. Intellij IDE berfungsi membantu dalam dunia percodingan baik dari segi navigasi, penyokong produktivitas, hingga code editor yang cerdas (Satyaputra dan Aritonang, 2016).

\subsubsection{Android}

Menurut Supardi (2015) Android merupakan sebuah sistem operasi perangkat mobile berbasis Linux yang mencangkup sistem operasi, middleware dan aplikasi.

Adanya perangkat android serta dengan kecanggihan yang ditawarkan dan kemudahan yang bisa didapatkan, banyak hal yang dapat diakses dimanapun kita berada. Oleh karena itu, bukanlah hal yang tidak mungkin apabila membuat sebuah aplikasi yang dapat meningkatkan layanan psikolog dalam melakukan skrining tumbuh kembang klien.

\subsubsection{Java}

Menurut Rusli, dkk (2016) Java adalah bahasa pemograman yang tergolong high level language (mudah bagi manusia untuk memahami), mengingat kata-kata/statementnya menyerupai bahasa manusia (english). Java disebut juga juga program sumber (source code) dan berekstensi .java (dot java). Java bersifat bebas platform, yang berarti bahwa program java dapat berjalan pada semua jenis sistem operasi. Java digunakan untuk membangun aplikasi Kuesioner Pra Skrining Perkembangan.

\subsubsection{PHP}

PHP (Hypertext Preprocessor) yaitu bahasa pemograman web server-side yang bersifat open source. PHP merupakan script yang terintegrasi dengan HTML dan berada pada server (server side HTML embedded scripting). PHP adalah script yang digunakan untuk membuat halaman website yang dinamis (Anhar, 2010).

\subsubsection{UML}

Menurut Hendini (2016) Unified Modeling Language (UML) adalah bahasa spesifikasi standar 
yang dipergunakan untuk mendokumentasikan, menspesifikasikan dan membangun perangkat lunak. UML merupakan metodologi dalam mengembangkan sistem berorientasi objek dan juga merupakan alat untuk mendukung pengembangan sistem.

\subsubsection{HTTP}

Menurut Zabar dan Novianto (2015) HTTP (Hypertext Transfer Protocol) adalah sebuah protokol jaringan lapisan yang digunakan untuk sistem informasi terdistribusi, kolaboratif dan menggunakan hipermedia. Digunakan untuk sistem sumber daya yang saling terhubung dengan suatu tautan (hiperteks) yang dikenal dengan World Wide Web (WWW) atau web yang ditemukan pada tahun 1990 oleh fisikawan Inggris Tim Berners-Lee. HTTP adalah sebuah protokol request/response antara klien dan server. Sebuah klien HTTP biasanya memulai permintaan dengan membuat hubungan port tertentu disebuah server web hosting tertentu (biasanya port 80

\subsubsection{JSON}

JSON (JavaScript Object Notation) adalah format pertukaran data yang ringan, mudah dibaca dan ditulis oleh manusia, serta mudah diterjemahkan dan dibuat (generate) oleh komputer. Format ini dibuat berdasarkan bagian dari bahasa pemograman JavaScript, standar ECMA-262 Edisi ke-3 - Desember 1999. JSON merupakan format teks yang tidak bergantung pada bahasa pemograman apapun karena menggunakan gaya bahasa yang umum digunakan oleh programmer keluarga $\mathrm{C}$ termasuk $\mathrm{C}, \mathrm{C}++, \mathrm{C} \#$, Java, JavaScript, Perl, Python dll. Oleh karena itu sifatsifat tersebut menjadikan JSON ideal sebagai bahasa pertukaran data

Struktur-struktur data ini disebut sebagai struktur data universal. Pada dasarnya, semua bahasa pemograman moderen mendukung struktur data ini dalam bentuk yang sama maupun berlainan. Hal ini pantas disebut demikian karena format data mudah dipertukarkan dengan bahasa-bahasa pemograman yang juga berdasarkan pada struktur data ini (Herdiana, 2014).

\section{Metode Penelitian}

Metode yang penulis gunakan adalah metode waterfall. Secara garis besar metode waterfall mempunyai langkah-langkah sebagai berikut : Analisa, Desain, Penulisan, Pengujian dan Penerapan serta Pemeliharaan. (Kadir, 2014).

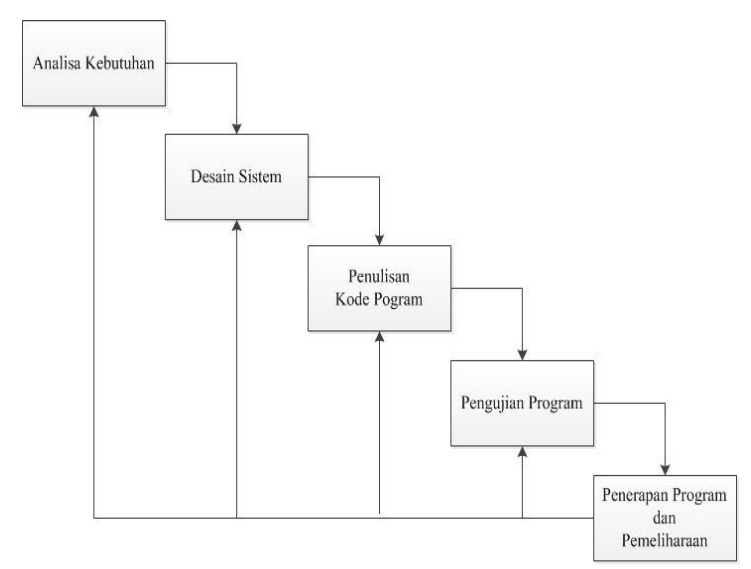

Gambar 1. Waterfall Model

(sumber : data olahan Kadir, 2014)

Tahapan Metode Waterfall (Kadir, 2014):

1. Analisa Kebutuhan

Langkah ini merupakan analisa terhadap kebutuhan sistem. Berikut beberapa teknik pengumpulan data yang dilakukan dalam tahap penelitian ini :

A. Pengamatan langsung (observasi), yaitu suatu teknik pengumpulan data dengan cara melakukan pengamatan langsung pada Hompimpa Center Bengkalis untuk mengetahui bagaimana cara kerja sistem yang sedang berjalan sehingga mendapatkan informasi untuk melakukan penerapan aplikasi KPSP.

B. Wawancara, yaitu metode pengumpulan data dengan cara berkomunikasi secara langsung dengan sumber data dan melakukan proses tanya jawab terhadap Ibu Eji Marlina selaku pimpinan Hompimpa Center Bengkalis, serta kepada beberapa karyawan dengan tujuan memperoleh data yang lebih objektif dan dapat memperoleh jawaban yang lebih mendalam.

C. Studi pustaka, yaitu dengan mempelajari buku-buku, referensi-referensi yang ada kaitannya dengan masalah yang dibahas untuk mendapatkan teori-teori dari permasalahan.

\section{Desain Sistem}

Tahapan menganalisa gambaran seperti apa system yang akan dibuat, bagaimana interface untuk setiap kegiatannya, serta mendefinisikan arsitektur system secara keseluruhan. Pada tahap perancangan ini peneliti mengguankan Unified Modeling Language (UML).

3. Penulisan Kode Program

Tahap penerjemahan data atau pemecahan masalah yang telah dirancang ke dalam bahasa pemograman tertentu. Pada penelitian ini, coding dilakukan menggunakan bahasa pemograman JAVA dengan menggunakan tools Android Studio, dengan nama database yaitu kpsp_db dan terdiri dari 5 tabel yaitu : table admin, tabel kuesioner, 
tabel pasien, tabel kuesioner pasien dan tabel pemeriksaan

4. Pengujian Program

Tahapan akhir dimana sistem yang baru diuji kemampuan dan keefektifannya sehingga didapatkan kekurangan dan kelemahan sistem yang kemudian dilakukan pengkajian ulang dan perbaikan terhadap aplikasi menjadi lebih baik dan sempurna. Pengujian dilakukan dengan uji coba black box untuk mendemonstrasikan fungsi sistem yang dioperasikan.

5. Penerapan Program dan Pemeliharaan

\section{Hasil dan Pembahasan}

\subsection{Hasil}

Tahap ini merupakan kegiatan pembuatan sistem atau aplikasi dengan menggunakan bantuan perangkat lunak maupun perangkat keras sesuai dengan analisis dan perancangan untuk menghasilkan suatu sistem yang bekerja.

A. Tampilan Icon Pada Android

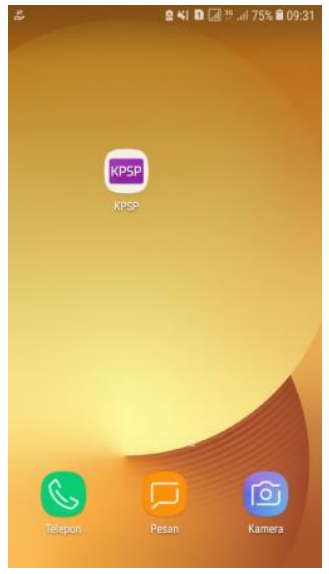

Gambar 2. Tampilan Icon Aplikasi Android (Sumber: Data Olahan)

B. Tampilan Halaman Splash Screen

Tampilan ini merupakan tampilan saat pertama kali menjalankan aplikasi KPSP di android.

\section{Tampilan Halaman Login}

Login aplikasi kuesioner pra skrinning perkembangan pada smartphone android yang telah dibuat untuk psikolog merupakan halaman login sekaligus pembuka atau halaman utama. Untuk melakukan proses login psikolog hanya perlu menginput password yang telah dibuat.

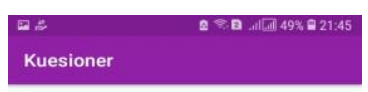

\section{KPSP}

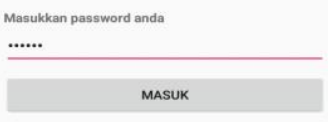

Gambar 4.Tampilan hamalam Login

(Sumber: Data Olahan)

D. Tampilan Halaman Beranda

Pada aplikasi ini memiliki 3 menu yaitu menu KPSP, menu data dan menu tentang. Pada menu KPSP merupakan tampilan yang berisikan penginputan biodata klien dan tampilan kuesioner. Pada menu data akan menampilkan data-data klien yang sudah melakukan skrinning dan menu tentang merupakan tampilan yang berisikan tentang profil dari pembuat aplikasi.

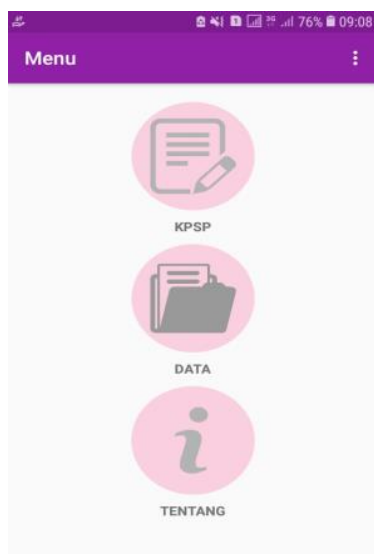

Gambar 5. Tampilan Halaman Beranda (Sumber: Data Olahan)

\section{E. Tampilan Input Biodata}

Pada tampilan ini psikolog menginput biodata klien sebelum memulai kuesioner. Pada penginputan biodata ini ada data yang boleh kosong dan tidak boleh kosong, salah satu yang boleh kosong yaitu pendidikan, karna tidak 
semua klien yang melakukan skrinning sudah memiliki pendidikan.

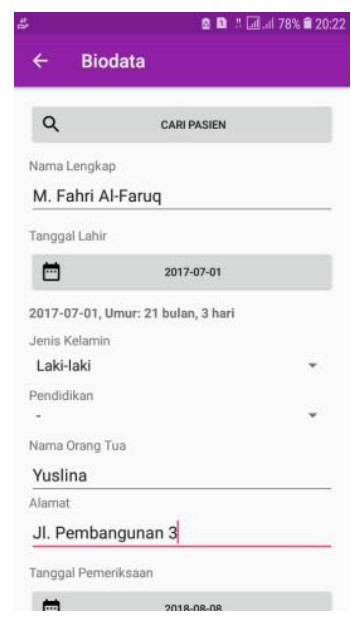

Gambar 6. Tampilan Input Biodata (Sumber: Data Olahan)

\section{F. Tampilan Kuesioner}

Tampilan ini menampilkan kuesioner klien setelah menginputkan biodata. Jenis kuesioner ini akan otomatis tampil pada aplikasi setelah diinputkan tanggal lahir klien, umtuk jawaban kuesioner terdiri dari 2 yaitu 'Ya' dan 'Tidak' .

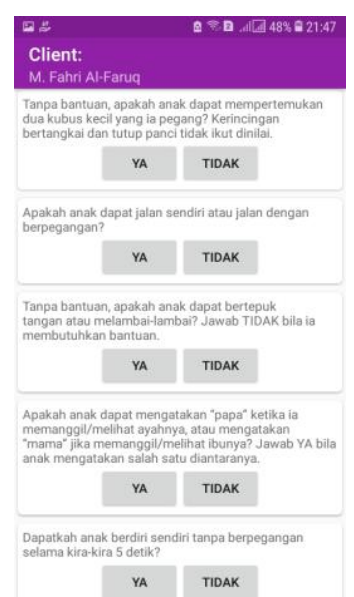

Gambar 7. Tampilan Kuesioner

(Sumber: Data Olahan)

\section{G. Tampilan Hasil Kuesioner}

Pada tampilan ini akan menampilkan hasil kuesioner klien setelah selesai menjawab semua pertanyaan. Tampilan ini juga menyediakan 2 tombol yaitu tombol print dan tombol rincian. Dengan ada nya tombol print psikolog bisa langsung mencetak hasil skrinning klien, dan untuk tombol rincian berisikan tentang rincian jumlah jawaban yang sudah dijawab.

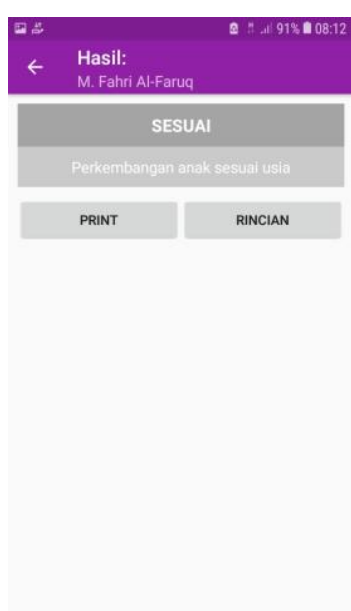

\section{Gambar 8. Tampilan Hasil Kuesioner} (Sumber: Data Olahan)

H. Tampilan Daftar Klien

Pada tampilan ini menampilkan list daftar klien yang telah melakukan skrinning perkembangan anak.

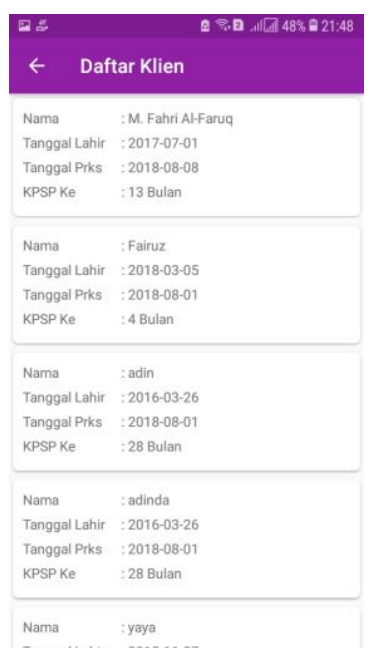

Gambar 9. Tampilan Data Anak

(Sumber : Data Olahan)

I. Tampilan Data Pemeriksaan

Tampilan ini merupakan tampilan data pemeriksaan klien secara detail. Pada tampilan ini juga menampilkan berapakali klien tersebut sudah melakukan skrinning, pada list hasil skrinning klien juga tersedia tombol print dan tombol hapus. 


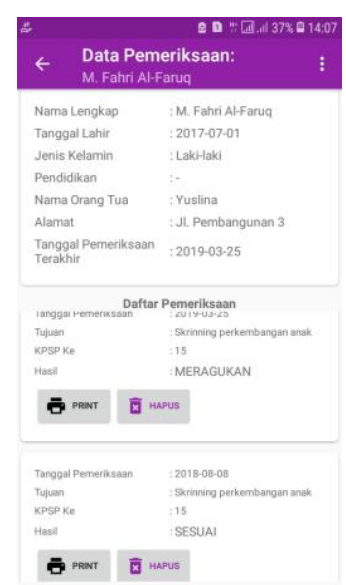

Gambar 10. Tampilan Detail Data Anak (Sumber: Data Olahan)

J. Tampilan Rincian

Tampilan ini menampilkan rincian jumlah jawaban ya dan jumlah Tidak dari kuesioner yang telah dijawab.

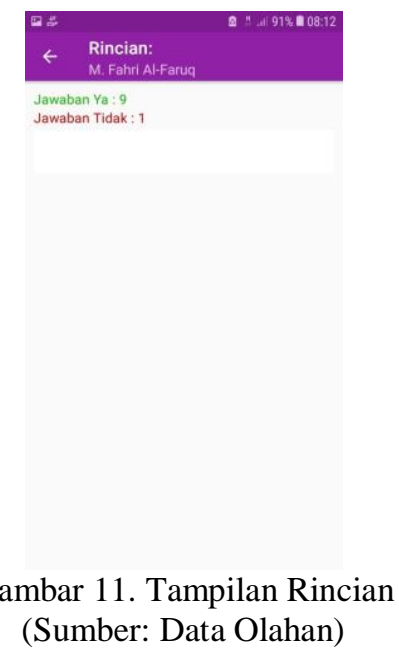

K. Tampilan Grafik

Tampilan ini menampilkan grafik perkembangan anak yang pernah melakukan skrinning.

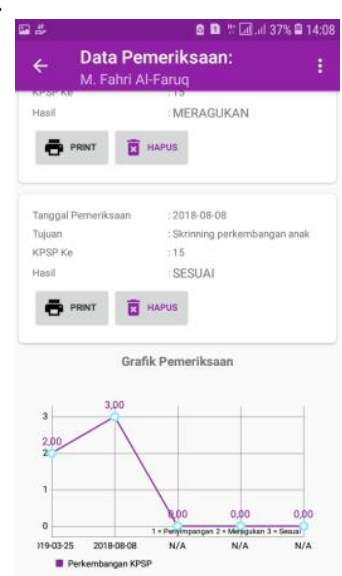

Gambar 12. Tampilan Grafik (Sumber: Data Olahan)

\section{Tampilan Tentang}

Tampilan ini berisikan tentang aplikasi, petunjuk dalam mengguanakan aplikasi serta profil dari pembuat aplikasi.

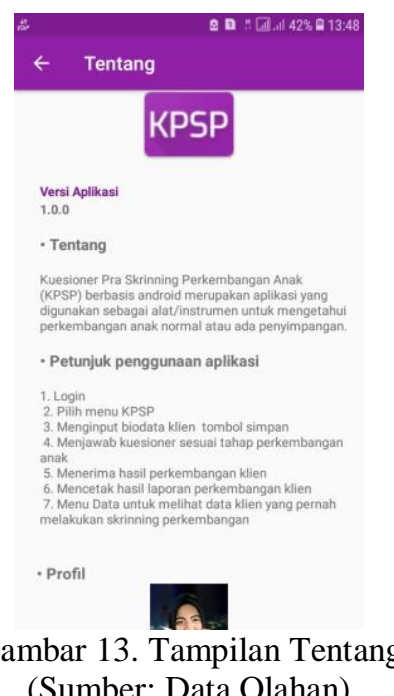

\subsection{Pengujian}

Pengujian dilakukan dengan menggunakan metode black box testing merupakan metode pengujian yang dilakukan hanya mengamati hasil eksekusi melalui data uji dan memeriksa fungsional perangkat lunak. Dengan menggunakan metode pengujian black box, perekayasa sistem dapat menemukan kesalahan yaitu:

1. Fungsi tidak benar atau hilang

2. Kesalahan antarmuka

3. Kesalahan pada struktur data (pengaksesan database)

4. Kesalahan inisialisasi dan akhir program

5. Kesalahan kinerja 
Tabel 1. Pengujian Perangkat

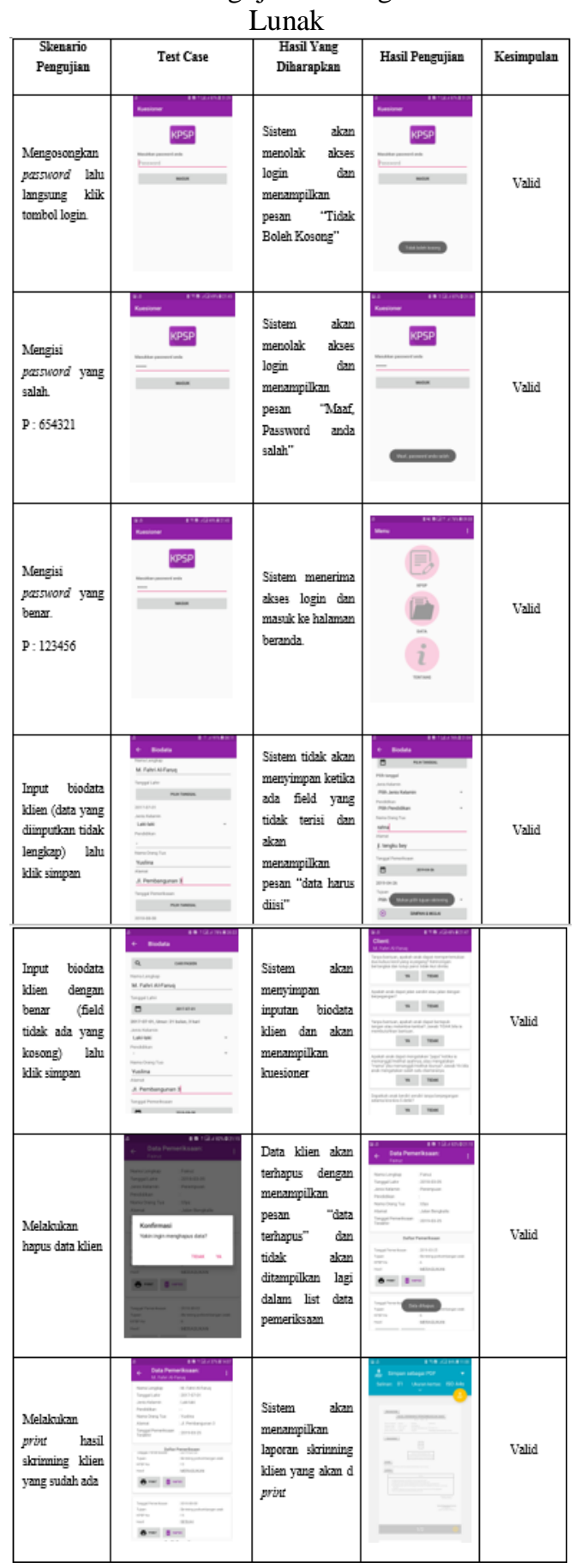

(Sumber: Data Olahan)

\section{Kesimpulan dan Saran}

\section{A. Kesimpulan}

Berdasarkan hasil penelitian pembuatan Aplikasi Kuesioner Pra Skrinning Perkembangan Anak Berbasis Android ini maka dapat diambil kesimpulan yaitu:

1. Penelitian ini menghasilkan Aplikasi Kuesioner Pra Skrinning Perkembangan Anak Berbasis Android yang mana dapat membantu kinerja psikolog dalam melayani klien yang memiliki masalah dalam perkembangan anak. Aplikasi ini juga memberikan efisiensi waktu serta mempermudah dan mempercepat kinerja psikolog.

2. Aplikasi ini dapat memberikan informasi tentang perkembangan anak dalam bentuk grafik, sehingga bisa mengetahui perkembangan anak secara periode.

\section{B. Saran}

Dari kesimpulan yang dijelaskan, maka dapat dikemukakan beberapa saran untuk pengembangan aplikasi kuesioner pra Skrinning Perkembangan Anak Berbasis Android ini yang lebih baik, diantaranya yaitu:

1. Aplikasi KPSP dapat dikembangkan dengan membatasi perhitungan umur anak dalam hitungan jumlah hari.

2. Aplikasi KPSP dapat dikembangkan dengan menambah fitur untuk lebih dari 1 pengguna.

3. Aplikasi KPSP hanya fokus pada masalah perkembangan anak. Untuk kedepannya aplikasi ini dapat dikembangkan dengan masalah pertumbuhan anak.

4. Aplikasi KPSP dapat dikembangkan untuk digunakan ditingkat pelayanan kesehatan primer, sekolah keperawatan dan sekolah PAUD.

\section{Daftar Pustaka :}

Anhar. (2010). Php \& MySQL secara Otodidak. Mediakita, Jakarta.

Ariestyani, M. K., Dkk. (2017). Klasifikasi Penyimpangan Tumbuh Kembang Anak Menggunakan Metode Extreme Learning Machine (ELM). Malang, Jurnal Pengembangan Teknologi Informasi dan Ilmu Komputer, 2(4):1628.

Departemen Kesehatan RI. (2006). Pedoman Pelaksanaan Stimulasi, Deteksi, dan Intervensi Dini Tumbuh Kembang Anak Di Tingkat Pelayanan Kesehatan Dasar. Jakarta, Depkes RI.

Dhamayanti, M. (2006). Kuesioner Pra Skrining Perkembangan (KPSP) Anak. Bandung, Sari Pedriati, 8(1):10.

Hendini, A. (2016). Pemodelan UML Sistem Informasi Monitoring Penjualan Dan Stok Barang. Pontianak, Jurnal Khatulistiwa Informatika, 4(2): 108.

Herdiana, Y. (2014). Aplikasi Rumus Matematik SMA Berbasis Mobile. Bandung, jurnal ilmiah komputer dan informatika (KOMPUTA), 2089:9033

Kadir, A. (2014). Pengenalan Sistem Informasi. Andi, Yogyakarta.

Mulyani, E. D. S., dan Restianie, I. N. (2016). Aplikasi Sistem Pakar Untuk Mendiagnosa 
Penyakit Anak (Balita) Dengan Menggunakan Metode Forward Chaining. Yogyakarta, Seminar Nasional Teknologi dan Multimedia, 3.4-47.

Rizqy, M. S., Dkk. (2015). Penerapan Model Hybrid Mobile Development Pada Deteksi Dini Tumbuh Kembang Balita Berbasis Android. Universitas Pakuan.

Rusli, M. Dkk. (2016). Belajar Pemograman Java Dengan Netbeans. CV. Andi Offset, Yogyakarta.

Satyaputra, A., dan Aritonang, E. M. (2016). Let's Build Your Android Apps with Android Studio. PT Elex Media Komputindo, Jakarta.

Saurina, N. (2016). Aplikasi Deteksi Dini Tumbuh Kembang Anak Usia Nol Hingga Enam Tahun Berbasis Android. Surabaya, Jurnal Buana Informatika, 7(1):65-74.

Supardi, Y. (2015). Belajar Coding Android bagi Pemula. PT Elex Media Komputindo., Jakarta.

Sutabri, T. (2012). Analisa Sistem Informasi. Andi, Yogyakarta.

Syafitry, D., Dkk. (2012) Sistem Pakar Gangguan Perkembangan Pada Balita Berbasis Web. Riau, Jurnal Aksara Komputer Terapan Politeknik Caltex Riau, 1(1):251.

Wati, D. E. (2016) Pengetahuan Guru PAUD Tentang KPSP (Kuesioner Pra Skrining Perkembangan) Sebagai Alat Deteksi Tumbuh Kembang Anak. Yogyakarta, Varia Pendidikan, 28(2):134.

Widodo, D. W., Dkk. (2014) Perancangan Sistem Pakar Deteksi Dini Tumbuh Kembang Anak Berbasis Multimedia. Yogyakarta, Jurnal Ilmiah SISFOTENIKA ,4(2):128.

Zabar, A. A., dan Novianto, F (2015) Keamanan HTTP dan HTTPS Berbasis Web menggunakan Sistem Operasi Kali Linux. Universitas Komputer Indonesia ,Jurnal Ilmiah Komputer dan Informatika (KOMPUTA), 4(2):100. 
Volume 6, Edisi 1, November 2019

$\mathbf{8 0} \mid \mathrm{H}$ a $\mathrm{l}$ a $\mathrm{m}$ a $\mathrm{n}$ 